\title{
Subsurface Investigation of the Energy Systems Research Laboratory Site at Oak Rídge National Laboratory
}

\author{
T. W. Oakes \\ K. E. Shank
}




\section{DISCLAIMER}

This report was prepared as an account of work sponsored by an agency of the United States Government. Neither the United States Government nor any agency Thereof, nor any of their employees, makes any warranty, express or implied, or assumes any legal liability or responsibility for the accuracy, completeness, or usefulness of any information, apparatus, product, or process disclosed, or represents that its use would not infringe privately owned rights. Reference herein to any specific commercial product, process, or service by trade name, trademark, manufacturer, or otherwise does not necessarily constitute or imply its endorsement, recommendation, or favoring by the United States Government or any agency thereof. The views and opinions of authors expressed herein do not necessarily state or reflect those of the United States Government or any agency thereof. 


\section{DISCLAIMER}

Portions of this document may be illegible in electronic image products. Images are produced from the best available original document. 


\section{Printed in the United States of America. Available from National Technical Information Service \\ U.S. [lepartment of r.nmmerre. 5285 Port Royal Road, Springfield, Virginia 22161 \\ Price: Printed Copy $\$ 4.00$; Microfiche $\$ 3.00$}

This report was prepared as an account of work sponsored by the United States Government. Neither the United States nor the Energy Research and Development Administration/United States Nuclear Regulatory Commission, nor any of their employees, nor any of their contractors, subcontractors, or their employees, makes any warranty, express or implied, or assumes any legal liability or responsibility for the accuracy, completeness or usefulness of any information, apparatus, product or process disclosed, or represents that its use would not infringe privately owned rights. 
ORNL/TM-5695

Contract No. H-7405-eng-26

SUBSURFACE INVESTIGATION OF THE ENERGY SYSTEMS RESEARCH

LABORATORY SITE AT OAK RIDGE NATIONAL LABORATORY

T. W. Oakes and K. E. Shank

Environmental Surveillance and Evaluation Section

INDUSTRIAL SAFETY AND APPLIED HEALTH PHYSICS DIVISION

Date Published: July 1977

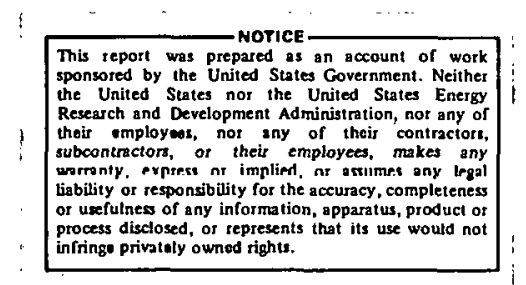

NOTICE This document contains information of a preliminary nature.

It is sublect to revision or correction and therefore does not reprosent a

final rannrt.

OAK RIDGE NATIONAL LABURA'IUKY

Oak Ridge, Tennessee 37830

operated by

UNION CARBIDE CORPORATION

for the

ENERGY RESEARCH AND DEVELOPMENT ADMINISTRATION 
THIS PAGE

\section{WAS INTENTIONALLY \\ LEFT BLANK}


CONTENTS

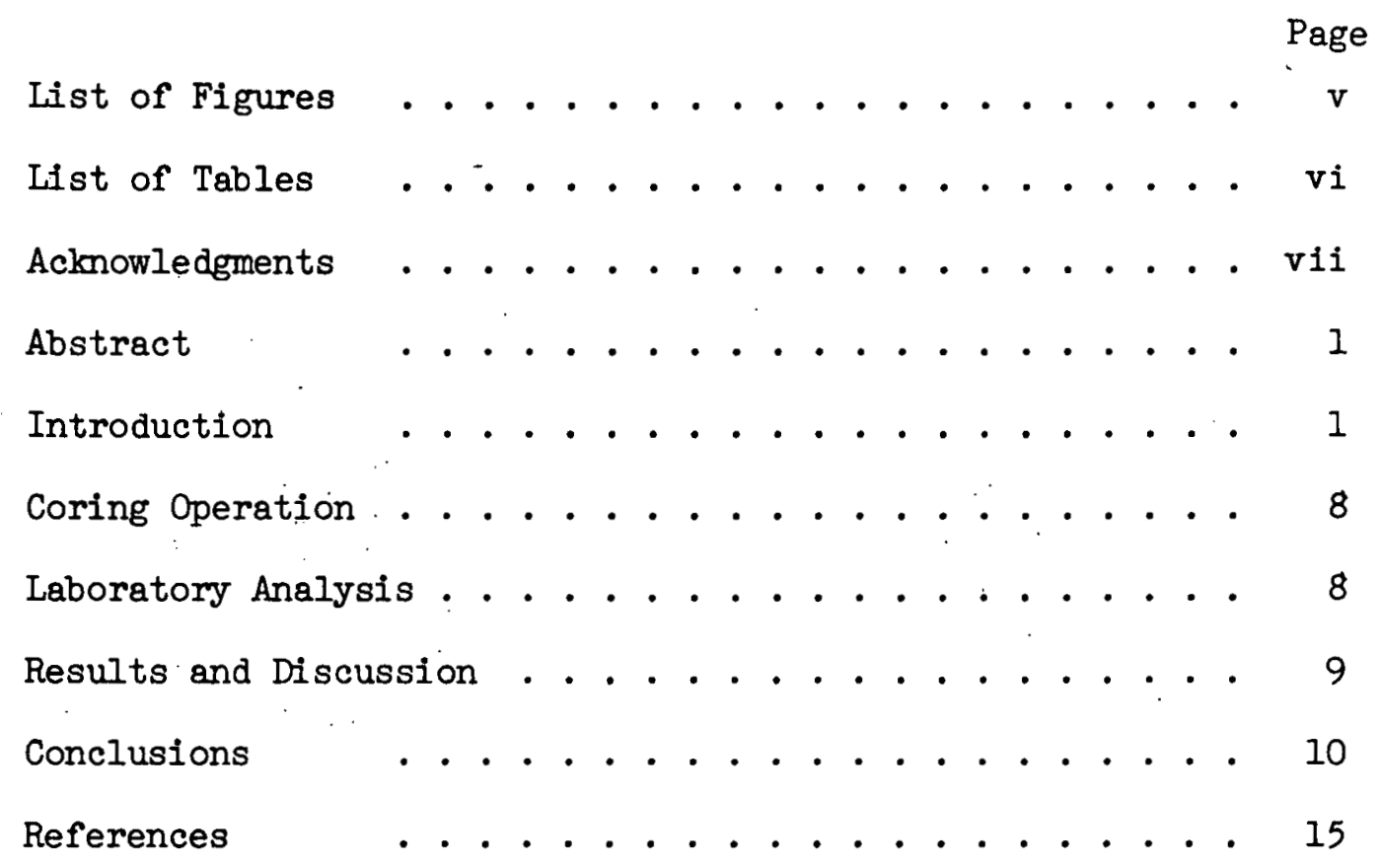


THIS PAGE

\section{WAS INTENTIONALLY \\ LEFT BLANK}


2 Aerial photograph of the existing ORNL site....

3. The ESRL site as seen from varlous viewpoints: (a) view of Substation Drive; (b) view from Substation Drive looking towards Bldg. 4500 North; ( $c$ and $d$ ) views of site from Central Avenue looking north towards Substation Drive ....... 4

4 Aerial photograph of SWSA-2 site as it appeared in 1944

5 Diagram of SWSA-2 site relative to present features. Position of trees shown is approximate. Location of former fence and roads at the site was taken from Oak Ridge National Laboratory Engineering Drawing No. E-559, dated February 1, 1947 . . . . 


\section{LIST OF TABLES}

\section{TABIES}

1 Results of radiochemical analyses of soil samples from initial corlng operation . . . . . . . . .

2 Results of gamm-spectrometric analyses of soil samples from second coring operation. . . . . .

3 Results of radiochemical analyses of soll samples frum second ooring nperation . . . . . . . . 


\section{ACKNOWLEDGMENTS}

The authors wish to recognize H. M. Hubbard and J. P. Sprain for their assistance in sample collection and preparation, and T. G. Scott and J. S. Eldridge for the radiochemical analyses. 


\title{
SUBSURFACE INVESTIGATION OF THE ENERGY SYSTEMS RESEARCH LABORATORY SITE AT OAK RIDGE NATIONAL LABORATORY \\ T. W. Oakes and K. E. Shank
}

\begin{abstract}
Subsurface soil from the site of the proposed Energy Systems Research Laboratory was examined to determine radioactive concentration levels. This study was undertaken because the proposed site is in close proximity to the former Solid Waste Storage Area-2. A total of 25 cores were taken, ranging in depth from 4 to 9 feet, and the soil samples were analyzed for gamma-, beta-, and alpha-emitting isotopes. Water taken from 13 of the core holes was analyzed to determine tritium, gross beta, and gross alpha levels. None of the samples analyzed were found to be significantly higher than background samples collected throughout eastern and central Tennessee. No special health physics precautions are expected to be needed for the excavation at the site, other than using the excavated soil as backfill at burial sites on the reservation.
\end{abstract}

\section{INTRODUCTION}

During April, 1976, the Plant and Equipment Division at Oak Ridge National Laboratory (ORNL) undertook an initial coring operation to determine the nature of subsurface materials for foundation of the proposed Energy Systems Research Laboratory (ESRL) and to examine subsurface soils for radioactive contamination. An additional coring operation was conducted in August, 1976, to further examine subsurface soil for radionuclide concentration levels. The site for the ESRL, northeasterm quadrant of ORNL at the intersection of Fifth Street and Central Avenue (Fig. 1), is in close proximity to the former Solid Waste Storage Area-2 (SWSA-2). An aerial photograph indicating the location of the SWSA-2 site is shown in Fig. 2. The proposed ESRL site as seen from various viewpoints is shown in Fig. 3. 


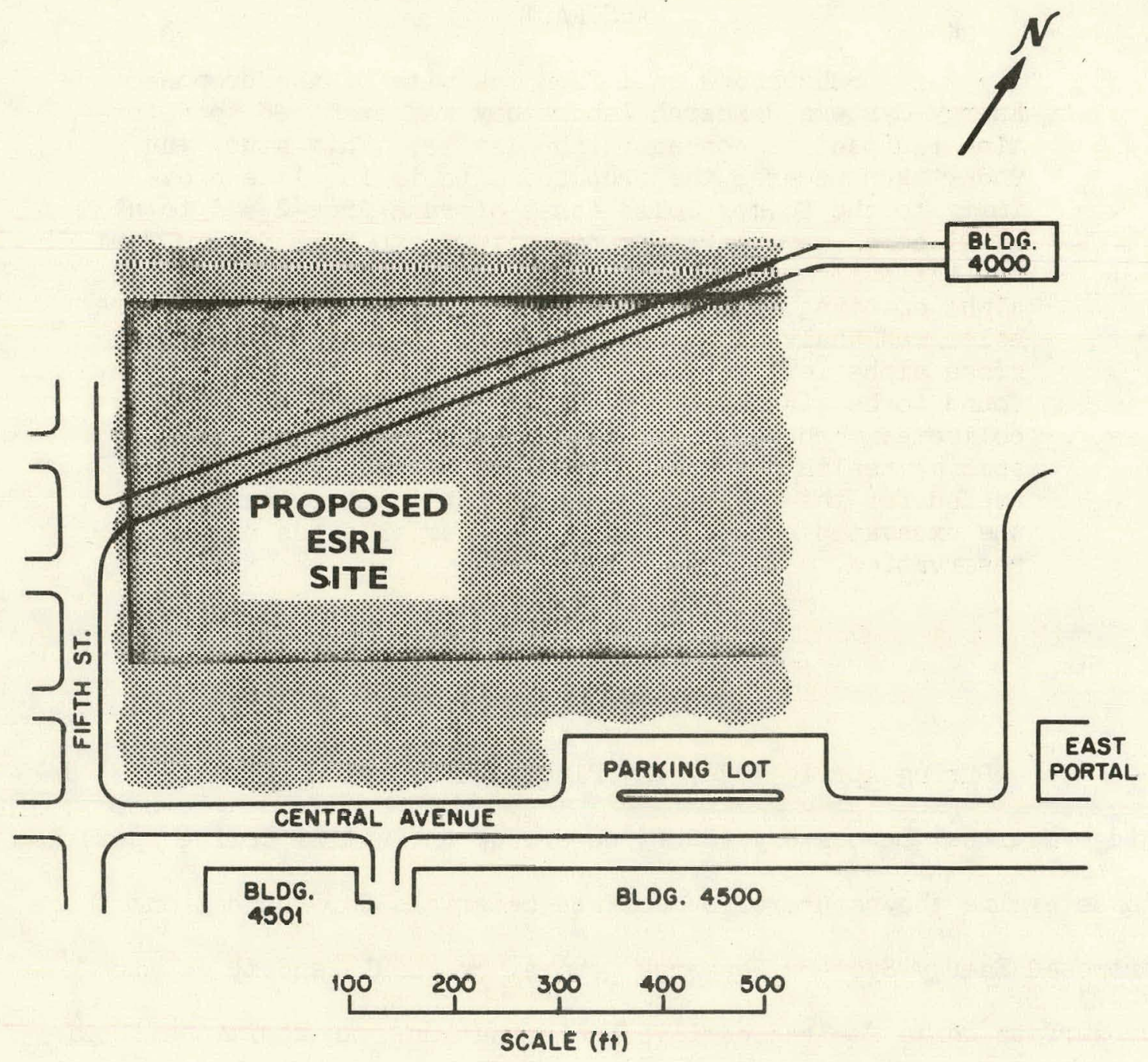

Fig. 1. Map of proposed ESRL site. 


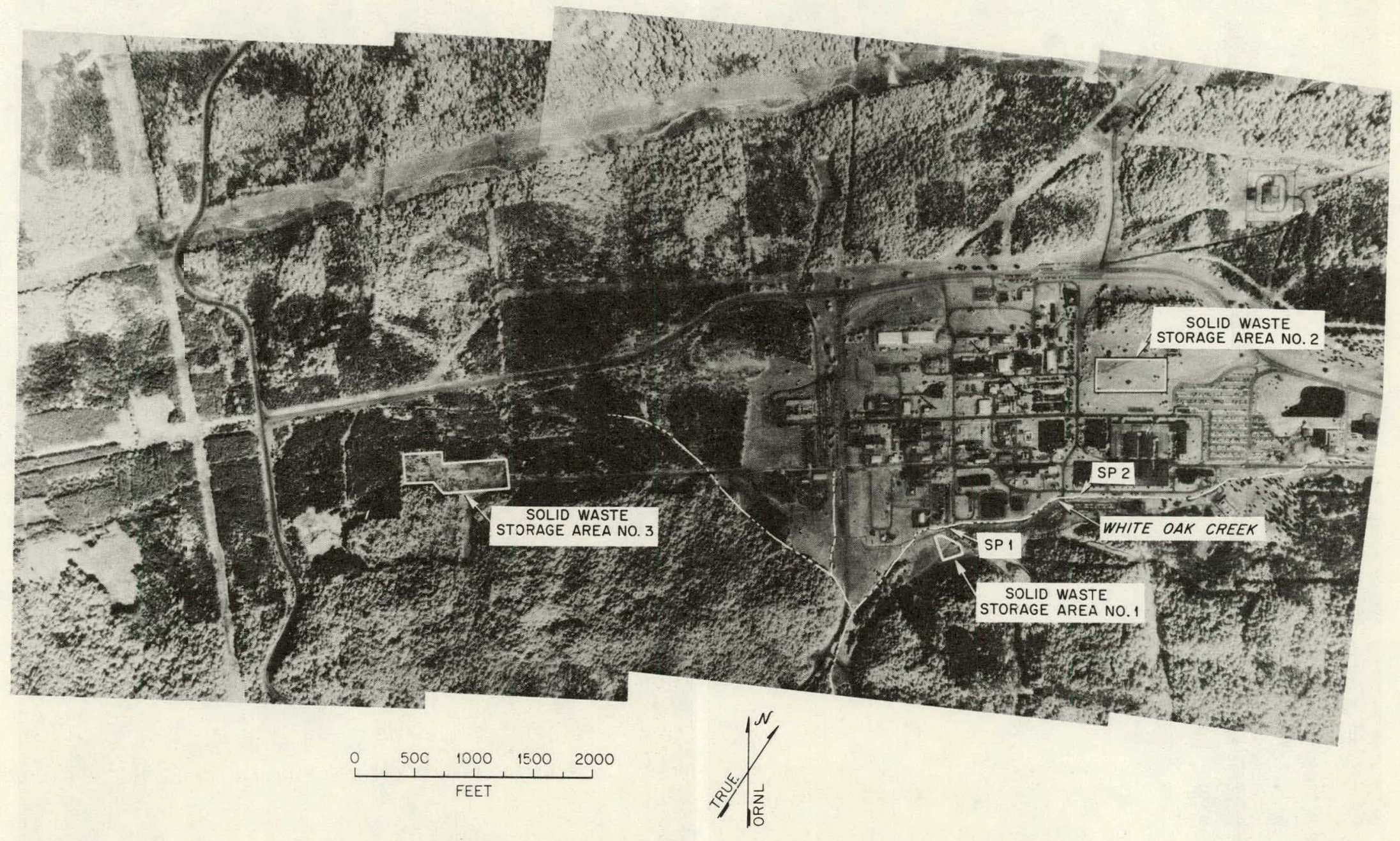

Fig. 2. Aerial photograph of the existing ORNL site. 


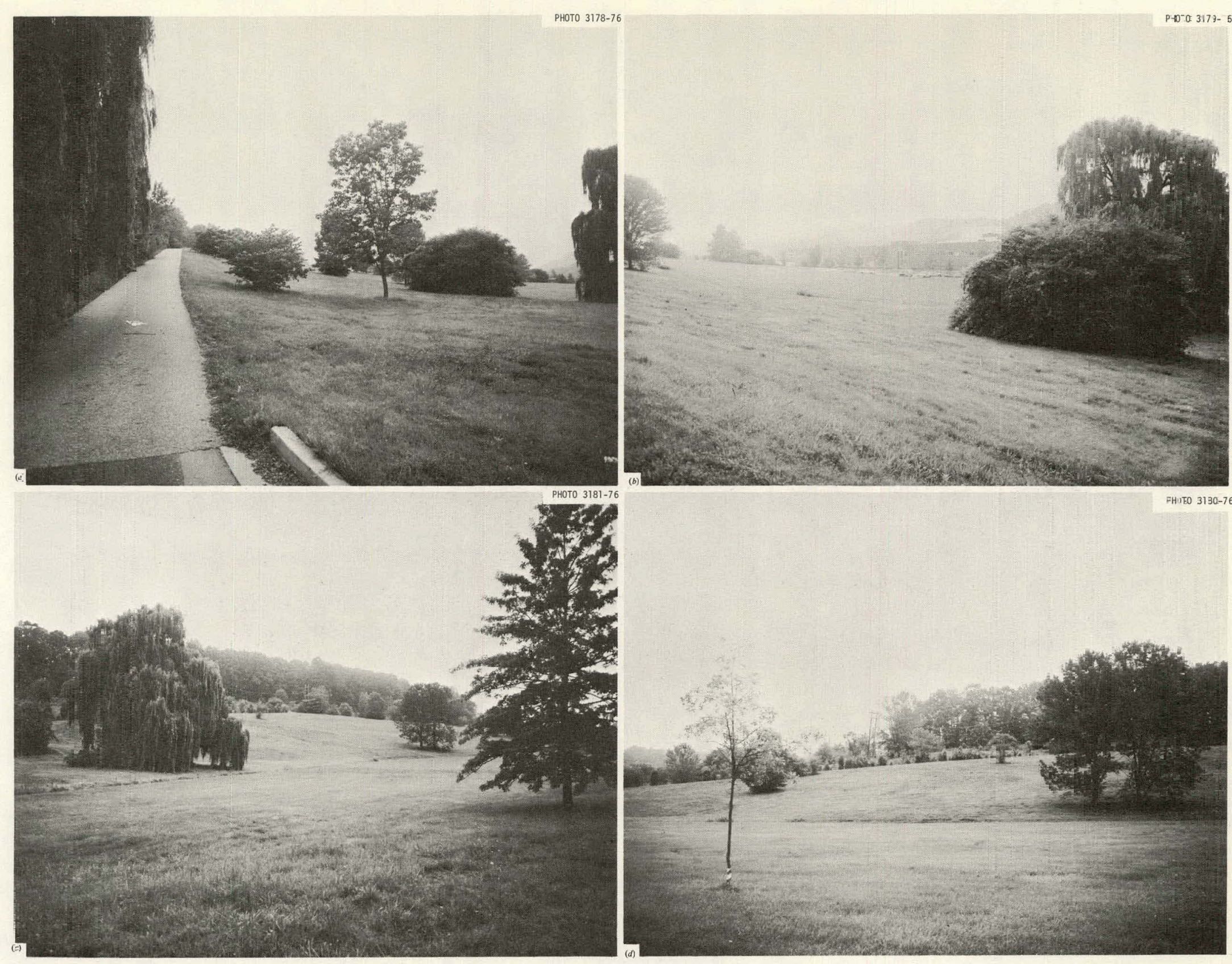

Fig. 3. The ESRL site as seen from various viewpoints: (a) view of Substation Dr:ve;

(b) view from Substation Drive looking towards Bldg. 4500 North; (c and d) iiews of site from Central Avenue looking north towards Substation Drive. 
Solid Waste Storage Area-2 was operated between 1943-1946, and it covered a total area of about four acres. Figure 4 is an aerial photograph of the SWSA-2 site as it appeared during operation; Fig. 5 is a diagram showing the location of SWSA-2 relative to present features. A comparison of Figs. 1 and 5 demonstrates the closeness of the ESRL proposed site to the area used for SWSA-2. During the operation of SWSA-2, wastes were dumped into open trenches which were then backfilled. There are no available records documenting the quantity or kind of solid waste disposed of in this area. ${ }^{1}$ It has been ascertained that solid waste contaminated by beta or gamma activity was placed in black iron drums and buried in the trenches. ${ }^{2}$ Liquid waste contaminated by plutonium was put in stainless steel drums and either buried in trenches or stored without burial in a "natural ravine" eroded in the denuded slope. Also, waste from an off-site source was buried and covered with concrete (suggestive of alpha contamination) near the present location of a transformer station. The use of the SWSA-2 site was later found to be incompatible with the long-range land-use planning at the Laboratory, and the operation was terminated in 1946. After closure, all the waste is said to have been exhumed and reburied in Burial Ground 3 (see Fig. 2). The stainless steel drums containing liquid plutonium waste were removed intact, but the black iron drums containing beta-gamma solid waste had deteriorated. Thus, the surrounding earth was also removed and reburied at Burial Ground 3. The hillside of the SWSA-2 site was then bulldozed to smooth out the irregularities, and it was seeded. ${ }^{2}$

Because of the possibility of encountering radioactive contamination during coring operations in the area of the proposed 


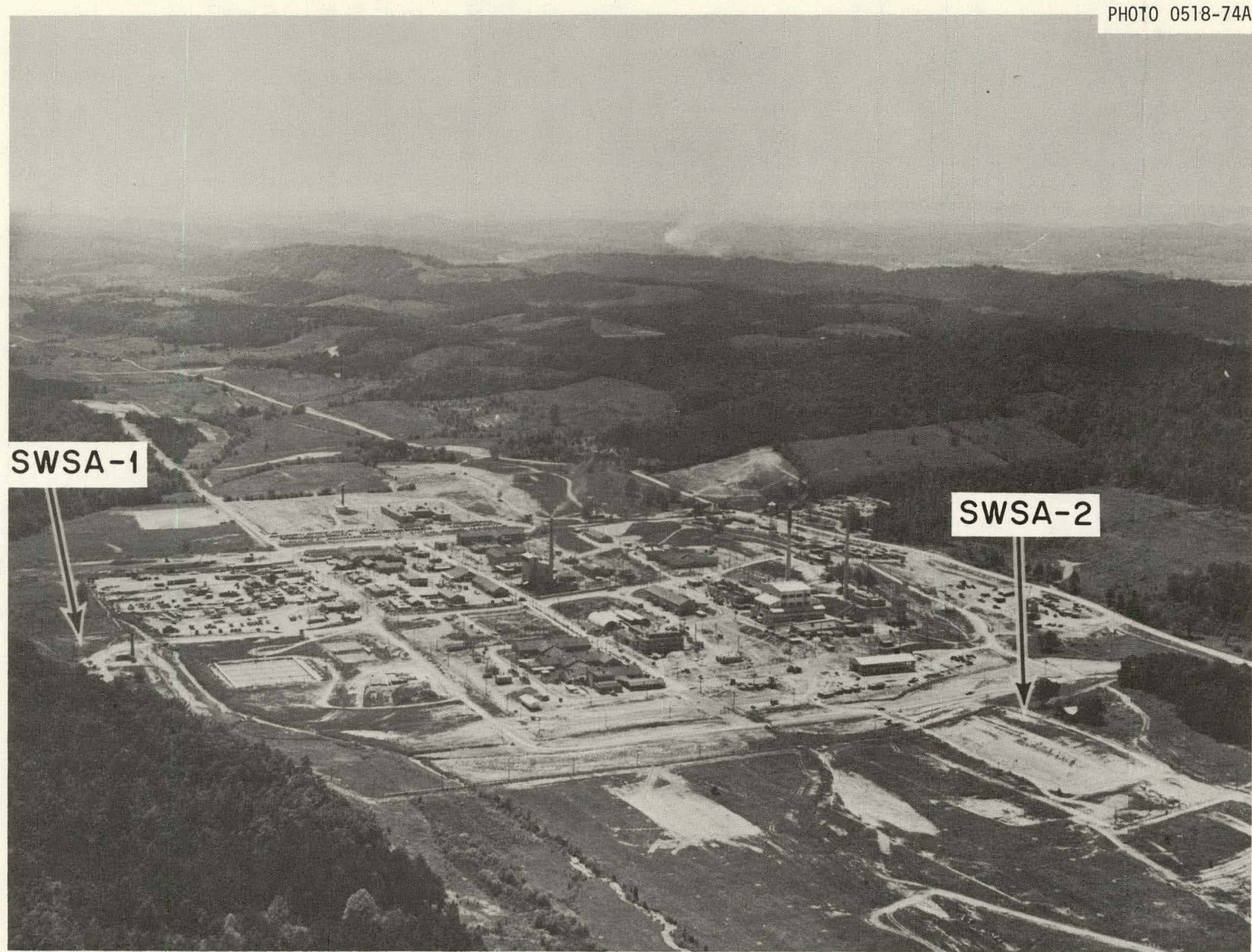

Fig. 4. Aerial photograph of SWSA-2 site as it appeared in 1944. 


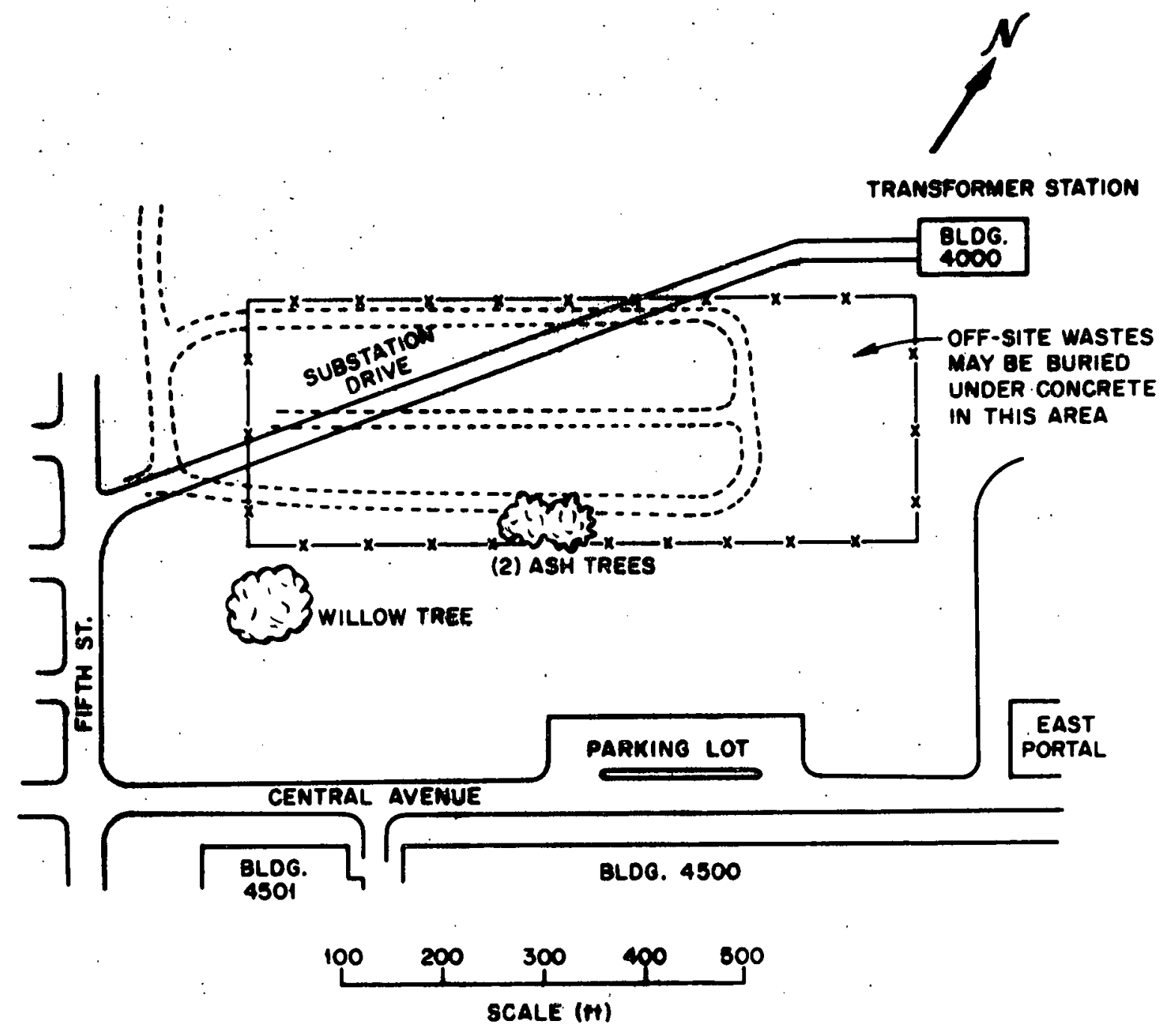

- $x-x$ - FORMER FENCE AROUND BURIAL GROUND

:

F1g. 5. Diggram of SWSA-2 site relative to present

features. Position of trees shown is approximate. Location of former fence and roads at the site was taken from Oak Ridge National Laboratory Engineering Drawing No. E-559, dated February 1, 1947 . 
building, the Radiation and Safety Survey Section of the Health Physics Division (now the Industrial Safety and Applied Health Physics DIvision) was requested to monftor the operations. The Environmental Monitoring Group (now the Environmental Survelllance and Evaluation Section) was given the responsibility for determining the radioactive concentration levels in soll and water samples removed from each core hole.

\section{CORING OPERATITON}

During the inital coring operations, 13 core samples were collected at the points indicated by the number notations. In Drawing X-20038-EA-005-E (pocket). Soll samples were collected and composited from each core, and taken to the laboratory for preparation. Sump pits were dug at each hole location for the collection of the water used during the drilling operations. At the completion of each drilling operation, a grab sample of water from the sump pit was collected, preparcd, and analyzed.

Twelve additional soil-sampling holes. were drilled during the second corlng operation at the points indicated by the letter notations on Drawing No. X-20038-EA-005-E (pocket). Core samples were collected, using a split-spoon sampler to the depth of bedrock. These core samples were separated into three sections for the determination of the radioactive concentration at different depths.

\section{LABORATORY ANALYSIS}

Each soll sample was dried for 24 hours at $110^{\circ} \mathrm{C}$ and then pulverized to a particle size of $500 \mu \mathrm{m}$. Aliquotes from each sample were transferred into twelve 30-cc polyethylene bottles and weighed. A specific gamma-emitting isotope analysis was performed on each sample. 
Counting of the samples was accomplished using a 50-ce Ge( $\mathrm{Li}$ ) detector system. The output of the detector was amplified and then analyzed using a Nuclear Data Model 3300 mult1 channel analyzer.

A 50-g aliquot from each soll sample was also taken for radiochemical analyses. Radiochemical separations were performed for ${ }^{90} \mathrm{Sr}$, thorium, uranium, and plutoni um assay. Alpha pulse-helght analyses were used for identification and assay of the thorium, uranium, and plutonium 1sotopes wlth ${ }^{234} \mathrm{Th},{ }^{232} \mathrm{U}$, and ${ }^{242} \mathrm{Pu}$, respectively; being used as tracers for yield corrections. These samples were counted using ORTEC and Princeton Gamma-Tech solid-state detectors. Concentrations of ${ }^{9} \mathrm{Sr}$ were determined with a Tracerlab low-background proportional counter.

\section{RESULTS AND DISCUSSION}

Activity levels in water samples were found not to be significantly different from baseline samples when analyzed for ${ }^{3} \mathrm{H}$, gross alpha and beta activity. Analytical results of the soil samples from the initial coring operations are presented in Table 1. A representative portion of the homogenized whole core was used for this analysis. The average uranium and plutonium concentrations were measured to be $0.47 \mathrm{pcl} / \mathrm{g}$ urrd 0.06 $\mathrm{pCi} / \mathrm{g}$, respectively. The average radioisotope concentration for soil samples near the perimeter alr monitoring stations at ORNL have been measured to contain $0.66 \mathrm{pCi} / \mathrm{g}$ of uranium and $0.04 \mathrm{pCi} / \mathrm{g}$ of plutonium. ${ }^{3}$ Because the average plutonium value for the cores was higher than those values of soil from perimeter locations and also since'selected samples, such as core numbers 12 and 15 (see Table 1), indicated significantly higher than normal levels, additional coring was requested.' These additional cores were divided into thirds for indications of changes in activity 
levels with depth. The results of these analyses are presented in Tables 2 and 3.

The average ${ }^{137} \mathrm{Cs}$ concentration for the upper third and the entire core was measured to be 0.7 and $0.3 \mathrm{pCl} / \mathrm{g}$, respectively (Table 2). Both of these values are substantially lower than the value of $1.0 \mathrm{pCi} / \mathrm{g}$, the average value of samples collected in 1976 from 16 sites throughout eastern and central Tennessee. ${ }^{4}$. It should be noted, however, that the soli samples for the coring operation extend several feet into the ground, whereas the results used in the comparisons were from soll samples of the first centimeter of topsoil.

For ${ }^{90} \mathrm{Sr}$ (Table 3), the average value for the cores from the site was found to be $\leq 0.57$ and $\leq 0.53 \mathrm{pCi} / \mathrm{g}$ for the upper third and the entire core, respectively. Further, the ${ }^{238} \mathrm{Pu}$ and ${ }^{239} \mathrm{Pu}$ ( Table 3) content of the entire core samples were found to be $\leq 0.0015$ and $\leq 0.014$ $\mathrm{pCi} / \mathrm{g}$, respectively, whereas the average values for other sites in eastern and central Tennessee have been reported ${ }^{4}$ to be 50.0021 and $0.014 \mathrm{pCi} / \mathrm{g}$. Results of the analysis of air filters from.local monitoring stations near the site indicated an average ${ }^{239} \mathrm{Pu}$ air concentration of $1.4 \times 10^{-17} \mu \mathrm{Ci} / \mathrm{ml}$, which is equivalent to fall-out levels detected at perimeter and remote stations. 3

\section{CONCLUSIONS}

The results of the analyses of the soll, water, and air filter samples on and near the proposed ESRL site do not indicate higher radioactive concentrations than baseline samples. In the same geographical location. However; since it is possible that the coring operations may have missed some "hot spots" on the site, it is recommended that the 
excavated soil be contalned on the control area of the ORNL Reservation and used as backfill in burial-ground operations. It.is also recommended that the excavation activities be overseen by a qualifled health physicist and other ORNL staff as deemed necessary. The excavation operations at this site should not pose any significant radioactive hazard to personnel working at the site, to other ORNL personnel, or to members of the general public. 
Table 1. Results of radiochemlcal analyses of soil samples from inftial coring operation.

( $\mathrm{pCl} / \mathrm{Dry}^{\circ} \mathrm{g}$ )

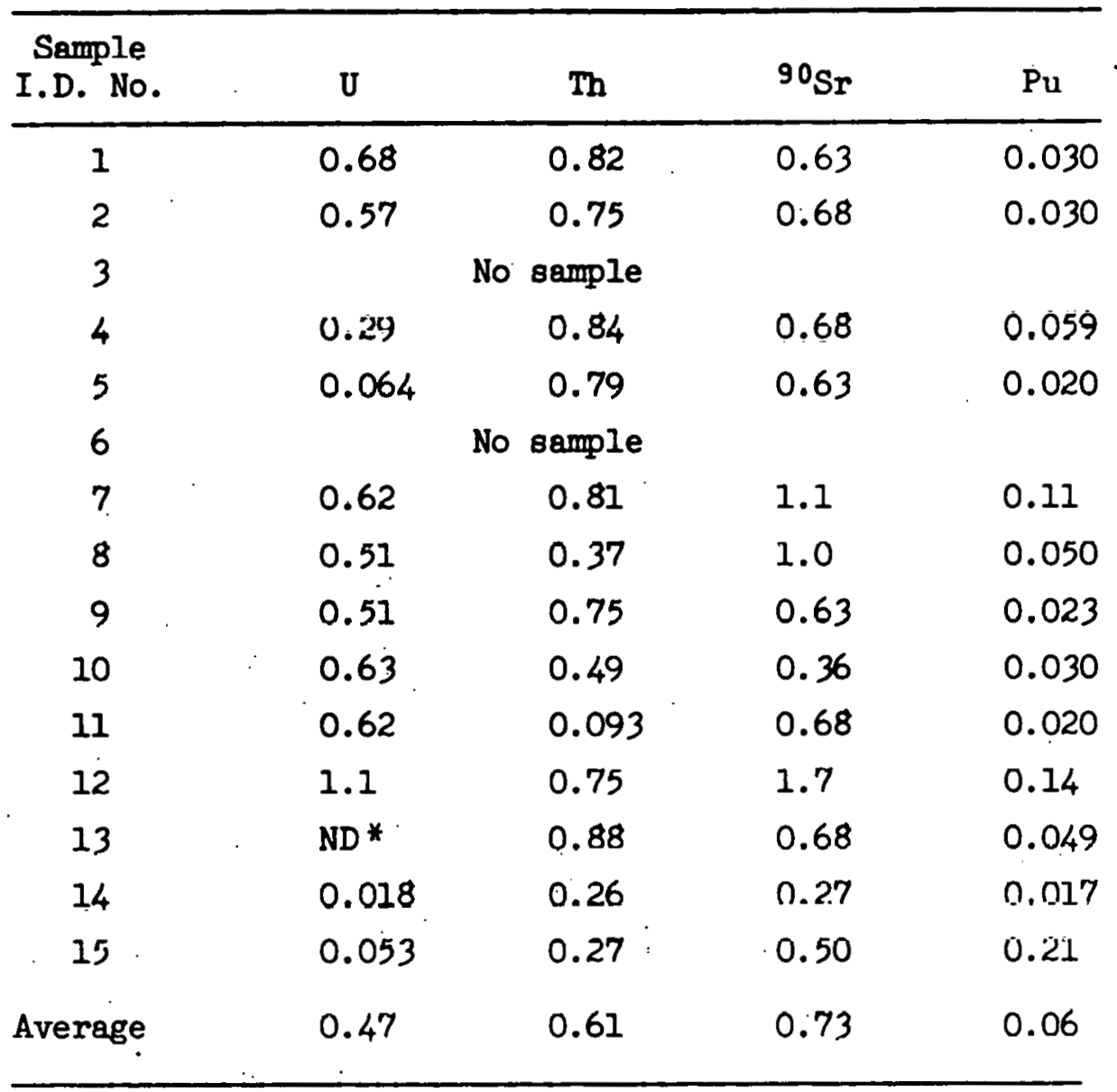

* Not detectable. 
Table 2. Results of gamma-spectrometric analyses of soil samples from second coring operation

( $\mathrm{pCl} /$ Dry g)

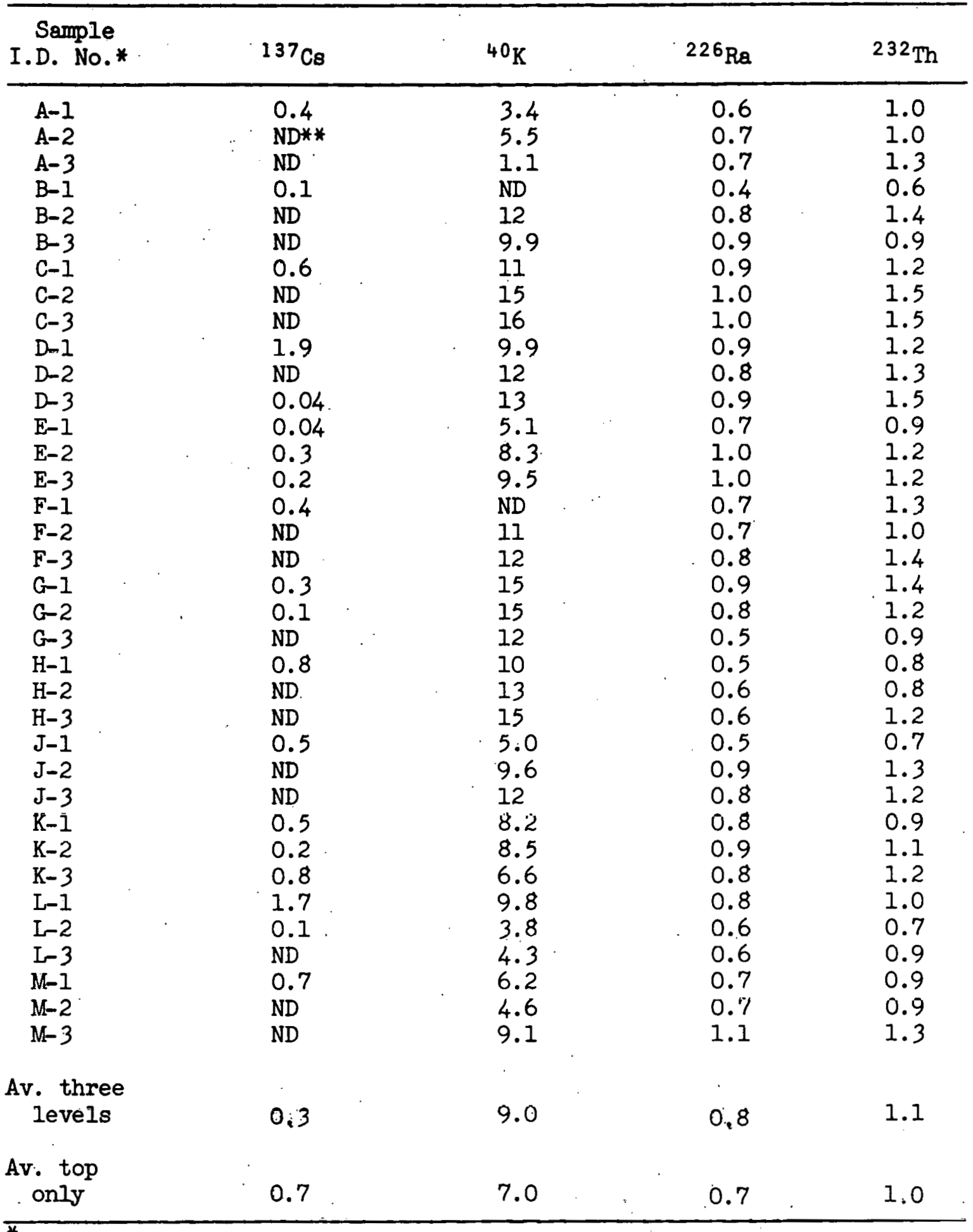

Each core was divided into thirds for analysis ( 1 is uppermost section; 3 is lowest).

** Not detectable. 
Table 3. Results of radiochemical analyses of soll samples from second corling operation

(pC1/Dry g)

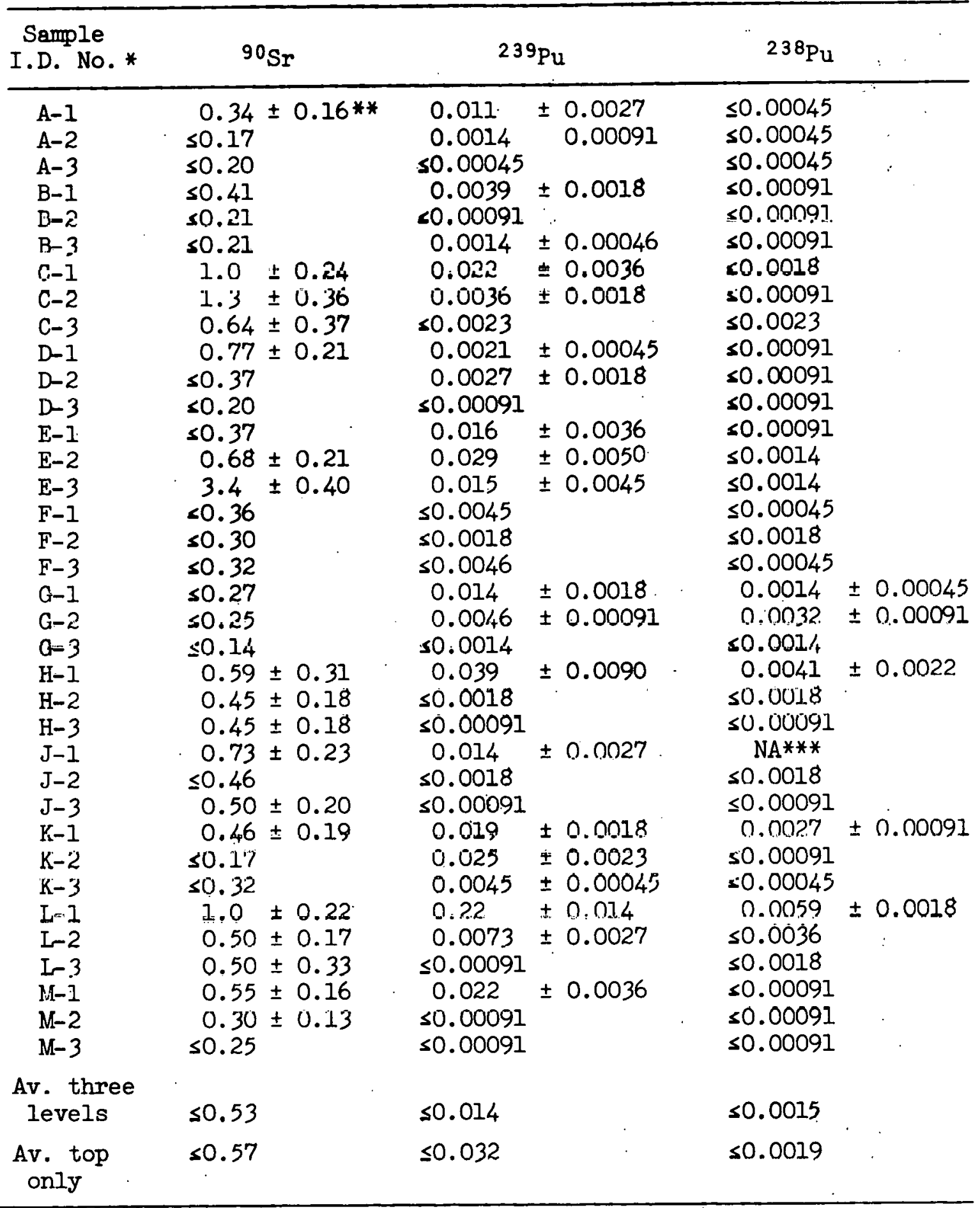

* Each core was divided into thirds for analysis ( 1 is uppermost section, 3 is lowest).

** Values at the $95 \%$ confidence level.

*** No analysis. 
REFERENCES

1. F. T. Binford, Oak Ridge National Laboratory, personal communication (1976).

2. Untted States Geological Survey, A Review of Bydrologic and Geologic Conditions Related to the Radioactive Solid-Waste Burial Grounds at oak Ridge National Laboratory, Tennessee, Report 76-727, 1976.

3. Applied Bealth Physics and Safety Annual Report, ORNL-5169 (1976).

4. T. W. Oakes, K. E. Shank, and C. E. Easterly, "Natural and Man-Made Radionuclide Concentrations in Tennessee Solls," in Proceedings of the Tenth Midyear Topical Symposizm of the Health Physics Society, Saratoga Spring8, New York, October 11-13, 1976. 


\section{THIS PAGE}

WAS INTENTIONALLY

\section{LEFT BLANK}


INTERNAL DISTRIBUTION

1. H. H. Abee

2. S. I. Auerbach

3. J. A. Auxier

4. F. T. Binford

5. F. R. Bruce

6. G. E. Burger

7. T. J. Burnett

8. H. M. Butler

9. G. C. Caln

10. R. L. Clark

11. F. L. Culler

12. R. C. Dahlman

13. D. M. Davis

14. J. 0 . Dugut d

15. J. S. Eldridge

16. L. D. Eyman

17. W. Fulkerson

18. C. R. Guinn

19. R. M. Holmes

20-21. I. N. Howell

22. D. G. Jacobs

23. E. M. King

24-38. T. W. Oakes

39. H. Postma

40. C. R. Ri chmond

41. M. W. Rosenthal

42. T. H. Row .

43. T. G. Scott

44-49. K. E. Shank

50-51. Central Research Library

52. Document Reference Section

53-55. Laboratory Records

56. Laboratory Records, ORNL RC

57. ORNL Patent Office

EXTERNAL DISTRIBUTION

58-59. Technical Information Center, ERDA, ORO

60. J. F. Wing, Environmental Protection Branch, ERDA, ORO

61. Director, Research and Technical Support Division, ERDA, ORO 